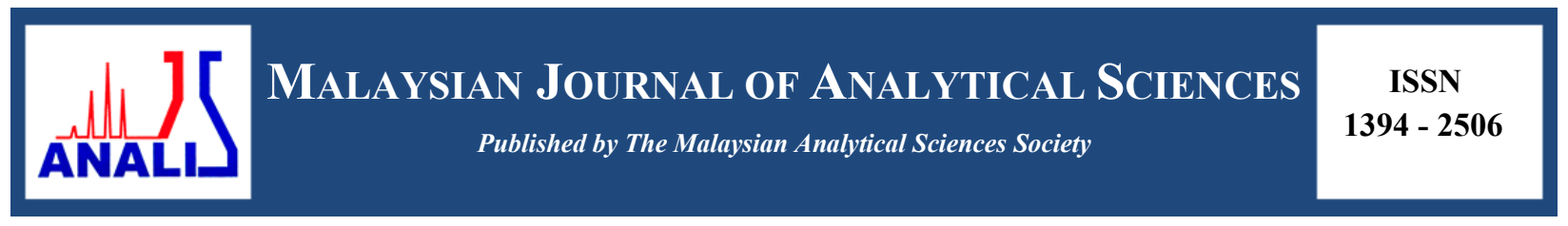

\title{
REMOVAL OF LEAD(II) FROM AQUEOUS SOLUTION USING POLYACRYLONITRILE/ZINC OXIDE ACTIVATED CARBON NANOFIBERS
}

\author{
(Penyingkiran Plumbum(II) daripada Larutan Akues Mengunakan Gentian Nano Karbon \\ Teraktif Poliakrilonitril/Zink Oksida) \\ Norfadhilatuladha Abdullah ${ }^{1,2}$, Muhamad Hanis Tajuddin ${ }^{1,2}$, Norhaniza Yusof ${ }^{1,2 *}$,Juhana Jaafar ${ }^{1,2}$, \\ Farhana Aziz ${ }^{1,2}$, Nurasyikin Misdan ${ }^{3}$ \\ ${ }^{1}$ Advanced Membrane Technology Research Centre (AMTEC) \\ ${ }^{2}$ Faculty of Chemical and Energy Engineering (FCEE) \\ Universiti Teknologi Malaysia, 81310 Skudai, Johor Bahru, Malaysia \\ ${ }^{3}$ Faculty of Engineering Technology, \\ Universiti Tun Hussein Onn Malaysia, 86400 Parit Raja, Johor, Malaysia \\ *Corresponding author: norhaniza@petroleum.utm.my
}

Received: 26 August 2016; Accepted: 8 January 2017

\begin{abstract}
This study aimed to prepare activated carbon nanofibers (ACNFs) from polyacrylonitrile (PAN) and zinc oxide (ZnO) via electrospinning process for removal of lead from aqueous solution. The ACNFs/ZnO were characterized in term of its morphological changes, specific surface area and functional groups analysis using Field Emission Scanning Electron Microscope (FESEM), Brunauer-Emmett-Teller (BET) and Fourier Transform Infrared (FTIR) analysis, respectively. The results showed that the specific surface area (SSA) of the ACNFs $/ \mathrm{ZnO}$ were higher than the neat ACNFs which were $163.04 \mathrm{~m}^{2} / \mathrm{g}$ as compared to $67.6 \mathrm{~m}^{2} / \mathrm{g}$, accordingly. FESEM analysis illustrated that composite ACNFs possessed more compact fibers with presence of $\mathrm{ZnO}$ beads and smaller fiber diameter whereas neat ACNFs possessed more aligned nanofibers with larger fiber diameter. Adsorption study showed that the composite ACNFs possessed higher capacity which was $120.3 \mathrm{mg} / \mathrm{g}$ as compared to $77.6 \mathrm{mg} / \mathrm{g}$ of neat ACNFs. This excellent adsorption performance of ACNFs PAN/ZnO exhibits the potential of this composite adsorbent to solve the environmental issue of heavy metal contamination.
\end{abstract}

Keywords: activated carbon, activated carbon nanofiber, adsorption capacity, lead adsorption

\section{Abstrak}

Kajian ini bertujuan untuk menyediakan gentian-nano karbon teraktif (ACNFs) daripada poliakrilonitril (PAN) and zink oksida melalui proses putaran-elektro untuk menyingkirkan plumbum (II) daripada larutan akues. ACNFs/ZnO dicirikan berdasarkan perubahan morfologi, luas permukaan spesifik, dan analisis kumpulan berfungsi mengunakan Mikroskopi Elektron Pengimbasan Pancaran Medan (FESEM), Brunauer-Emmett-Teller (BET) dan Inframerah Transformasi Fourier (FTIR). Keputusan kajian menunjukkan luas permukaan spesifik (SSA) komposit ACNFs adalah lebih tinggi berbanding ACNFs tanpa logam oksida iaitu $163.04 \mathrm{~m}^{2} / \mathrm{g}$ berbanding $67.6 \mathrm{~m}^{2} / \mathrm{g}$. Analisis FESEM menunjukkan komposit ACNFs mempunyai gentian lebih padat dengan kehadiran manik zink oksida and mempunyai diameter gentian lebih kecil manakala ACNFs tanpa logam oksida mempunyai gentian lebih tersusun dengan diameter gentian yang lebih besar. Ujian penjerapan menunjukkan bahawa penyingkiran $\mathrm{Pb}(\mathrm{II})$ menunjukkan kapasiti penjerapan yang lebih tinggi, iaitu $120.0 \mathrm{mg} / \mathrm{g}$ berbanding $77.6 \mathrm{mg} / \mathrm{g}$ oleh ACNFs tanpa ZnO. Hasil kajian ini menunjukkan potensi PAN/ZnO ACNFs sebagai penjerap untuk menyelesaikan isu pencemaran logam berat dalam persekitaran. 


\section{Norfadhilatuladha et al: REMOVAL OF LEAD(II) FROM AQUEOUS SOLUTION USING \\ POLYACRYLONITRILE/ZINC OXIDE ACTIVATED CARBON NANOFIBERS}

Kata kunci: karbon teraktif; gentian nano karbon teraktif, kapasiti penjerapan, penjerapan plumbum

\section{Introduction}

Recently, contamination of water by heavy metals has becomes a major concern among researchers. Their exposure towards human and enviroment could cause acute effects due to their non-degradable property and their rapid bioaccumulation into body system [1]. In water, some heavy metals that are commonly present are cadmium, arsenic, copper, iron, manganese and lead. Out of these hazardous heavy metals, the removal of lead $(\mathrm{Pb})$ has been extensively studied. In general, the major athrophogenic source of Pb disposal is mainly from industry, such as from leaded gasoline, leaded pipes, building construction, radiation shields, battery industries as well as lead smelting and bearings [2]. The effects of $\mathrm{Pb}$ exposure are well documented in which even a very small amount of $\mathrm{Pb}$ will results acute effects to nervous system, hematopoeitic system, cardicac and vascular system, metabolism, reproductive system and immune system [3]. To date, the maximum contaminant level (MCL) of Pb in drinking set by World Health Organization (WHO) and US Environmental Protection Agency (USEPA) is $15 \mu \mathrm{g} / \mathrm{L}$ [3]. With the increasing development of industrilization, the amount of $\mathrm{Pb}$ being released into water streams will aggravate. Therefore, the elevated amount of $\mathrm{Pb}$ in water is an important matter to be concerned.

Due to hazardous exposure of $\mathrm{Pb}$ on human and environment, there are various techniques have been implied for its removal from water streams; such as coagulation-flocculation, precipitation, ion exchange, membrane technology and adsorption [4]. Among the mentioned methods, adsorption stands as a promising techniques for removing heavy metals in which the process is relatively simple, effective and economic. In brief, adsorption is a process whereby the adsorbents are attached on the surface of solid or adsorbent [4]. There are wide range of adsorbents have been used for removal of $\mathrm{Pb}$ (II) such as natural products, zeolite, aluminosilicate, peat, clay, and activated carbon [5]. Among the wide range adsorbents, carbon-based materials particularly activated carbon (ACs) has become as one of the commonly used adsorbent for $\mathrm{Pb}(\mathrm{II})$ adsorption ascribed by their highly porous and high specific surface area [5]. In recent years, studies have been focusing on the development of activated carbon in nanofiber form (ACNFs). The developed ACNFs have been reported to possess smaller pore diameter with more concentrated pore size distribution which this properties are required for adsorption process [5].

There are several methods can be used to fabricate nanofibers such as melt fibrillation, island-in-sea, electrospinning and gas jet technique [6]. Nevertheless, it seems that electro-spinning process as shown in Figure 1 provides more advantages in term of high production rate and relatively low in cost as compared to the other techniques mentioned previously. To prepare electrospun ACNFs, polymer polyacrylonitrile (PAN) serves as an excellent carbon precursor as it has high carbon yield as compared to other carbon precursors [6]. Recently, many researchers had focused on incorporating various metal oxides such as magnesium oxide, iron oxide, zinc oxide, aluminium oxide and manganese oxide as additive in the dope suspension of ACNFs [7]. Adding metal oxides such as zinc oxide can enhance adsorption capacity as it is reported that these additives can improve the properties of the ACNFs $[8,9]$. Thus, the aim of this study is to fabricate ACNFs based polyacrylonitrile (PAN) as carbon precursor and zinc oxide as additive by electrospinning process. The prepared ACNFs were evaluated based on its physicochemical properties as well as it adsorptive performance towards $\mathrm{Pb}(\mathrm{II})$ from aqueous solution.

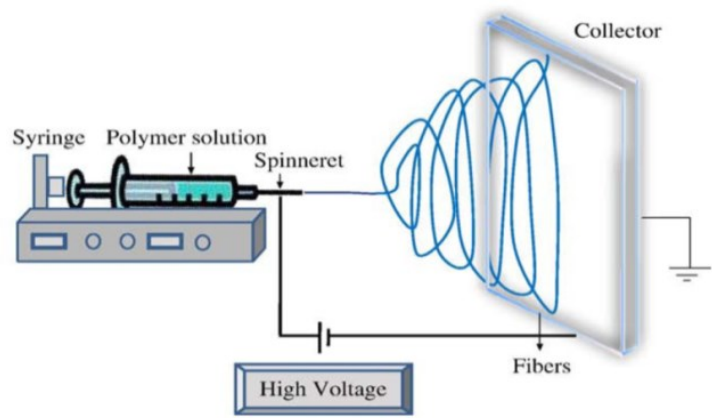

Figure 1. Schematic setup for electrospinning process [7] 


\section{Materials}

\section{Materials and Methods}

Polyacrylonitrile (PAN) with molecular weight of 150kDa was purchased from Sigma Aldrich (USA). Similarly, N,N-Dimethylformamide (DMF) and zinc oxide (ZnO) powder with 99\% purity were purchased from Alfa Aesar. Stock solution of $\mathrm{Pb}$ (II) was prepared using lead nitrate $\left(\mathrm{Pb}^{2} \mathrm{NO}^{3}\right)$ powder (Sigma Aldrich, USA) while the $\mathrm{pH}$ of heavy metal solution was adjusted by using $0.1 \mathrm{~mol}$ of $\mathrm{NaOH}$ and $\mathrm{HCl}$.

\section{Preparation of PAN-ZnO nanofibers by electrospinning}

Initially, dope solution of PAN-ZnO was prepared by stirring 5 wt.\% of ZnO powder with N-N dimethylformamide (DMF) for 5 hours followed by addition of $10 \mathrm{wt} \%$ polyacrylonitrile (PAN). The mixture was again continuously stirred for another 24 hours to obtain a homogenous solution. The dope solution was later subjected to electrospinning process under the electric field of $12 \mathrm{kV}$, suspension rate of $1.0 \mathrm{~mL} /$ hour and distance of $20 \mathrm{~cm}$. The collected nanofibrous mats were allowed to dry for at least a day prior to carbonization and activation process.

\section{Preparation of PAN-ZnO ACNFs}

The PAN-ZnO nanofibrous mats were later subjected to three pyrolysis processes: 1) stabilization; 2) carbonization and 3) activation following procedure [10]. The nanofibers were stabilized in pure air at temperature of $250{ }^{\circ} \mathrm{C}$ for 4 hours with heating rate of $1{ }^{\circ} \mathrm{C} / \mathrm{min}$. For the carbonization process, the process was carried out in nitrogen gas at temperature of $325^{\circ} \mathrm{C}$ for 1.5 hours with heating rate of $3{ }^{\circ} \mathrm{C} / \mathrm{min}$. Lastly, the carbonized nanofibers were activated at a heating rate of $3{ }^{\circ} \mathrm{C} / \mathrm{min}$ with under carbon dioxide until temperature at $425{ }^{\circ} \mathrm{C}$. The physicochemical properties of the end product which is activated carbon nanofibers (ACNFs) was characterized as described in section 2.4. Figure 2 shows the procedures of ACNFs fabrication.

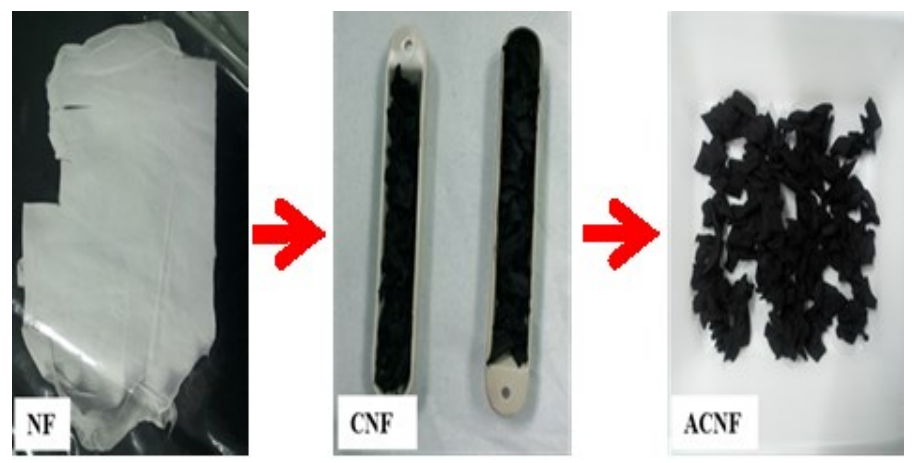

Figure 2. Preparation of nanocomposite $\mathrm{ACNFs} / \mathrm{ZnO}$

\section{Characterization}

In this study, characterizations were carried out in term of specific surface area (SSA), morphological structures and functional groups analysis by BET, FESEM-EDX and FTIR, respectively. To analyze the specific surface area of NFs and ACNFs, the specific surface area was determined by using automatic Tristar 3000 volumetric system. The surface morphologies of the ACNFs were examined using Field Emission Scanning Electron Microscopy (FESEM) respectively. The samples were placed on a staph and were sputtered with gold prior of FESEM analysis. The distribution and presence of $\mathrm{Zn}$ particles were analyzed by EDX, which was conducted by using the images captured by FESEM analysis. The functional groups present in PAN-ZnO ACNFs were identified using ATR-FTIR spectrometer (Model: IRTRACE100, Shimadzu). The samples were scanned by single-reflectance ATR accessory with IRTRACER100. The sample was prepared by cutting it into a small pieces and scanning at a wavelength 400 $\mathrm{cm}^{-1}$ to $4000 \mathrm{~cm}^{-1}$. 


\section{$\mathrm{Pb}(\mathrm{II})$ adsorption study}

The adsorptive performance of ACNFs on lead removal was conducted by studying the effect of initial $\mathrm{pH}$ and initial concentration. In every sample, $0.01 \mathrm{~g}$ of neat ACNFs and composite ACNFs was added into $10 \mathrm{~mL} \mathrm{~Pb}$ (II) solution. The solution was agitated for 48 hours in rotary shaker. The $\mathrm{pH}$ was adjusted using $0.1 \mathrm{~mol}$ of $\mathrm{NaOH}$ and HCI. The equilibrium concentrations of each samples was measured by filtering the samples and analyzed using Atomic Absorption Spectrometer (AAS) (model 4100ZL, Perkin Elmers).

The removal efficiency, $\mathrm{R}(\%)$ and adsorption capacity of prepared PAN-ZnO ACNFs were calculated using equation 1 and 2, respectively [9]:

$$
\begin{aligned}
& R(\%)=\left(C_{0}-C_{e}\right) / C_{o} \times 100 \\
& q_{e}(m g / g)=\left(C_{0}-C_{e}\right) V / m
\end{aligned}
$$

where $C_{o}$ is initial concentration of metal $(\mathrm{mg} / \mathrm{L}) ; C_{e}$ is equilibrium concentration of metal $(\mathrm{mg} / \mathrm{L}) ; V$ is volume of solution in (L) and $m$ is mass of adsorbent.

\section{Adsorption isotherm}

Adsorption isotherm analysis was conducted to analyze the adsorption behavior of ACNFs for the removal of $\mathrm{Pb}$ (II) ions from aqueous solution. The linear equations of Langmuir and Freundlich models are described from equation 3 and 4 , respectively [9].

$$
\mathrm{C}_{\mathrm{e}} / \mathrm{q}_{\mathrm{e}}=1 / \mathrm{Q}_{\max } \mathrm{b}+\mathrm{C}_{\mathrm{e}} / \mathrm{Q}_{\max }
$$

where $q_{e}$ is amount of $\mathrm{Pb}(\mathrm{II})$ adsorbed to adsorbent $(\mathrm{mg} / \mathrm{g}) ; C_{e}$ is equilibrium concentration of metal (mg/L). $Q_{\max }$ is maximum adsorption capacity $(\mathrm{mg} / \mathrm{g})$ and $b$ is the Langmuir constant.

$$
\ln \mathrm{q}_{\mathrm{e}}=\ln \mathrm{KF}+(1 / \mathrm{n}) \ln \mathrm{C}_{\mathrm{e}}
$$

$q_{e}$ is amount of $\mathrm{Pb}$ (II) adsorbed to adsorbent $(\mathrm{mg} / \mathrm{g}) ; C_{e}$ is equilibrium concentration of metal $(\mathrm{mg} / \mathrm{L}) ; K_{F}$ is the Freundlich constant $(\mathrm{mg} / \mathrm{g})$ and $1 / n$ is parameter related to adsorption intensity.

\section{Characterizations of PAN-ZnO ACNFs}

\section{Results and Discussion}

\section{Specific surface area}

Table 1 shows the specific surface area (SSA) of ACNFs and ACNFs/ZnO after activation process. From the table, it can be seen that addition of $\mathrm{ZnO}$ in the ACNFs increased the specific surface area from $67.60 \mathrm{~m}^{2} / \mathrm{g}$ for neat ACNFS to $163.04 \mathrm{~m}^{2} / \mathrm{g}$ for composite ACNFs $/ \mathrm{ZnO}$. The larger specific surface area could be resulted from the role of metal oxides (in our study, $\mathrm{ZnO}$ ) that acts as catalyst that accelerates the process of carbonization and activation. As results, more pores were created which contributes to larger specific surface area [8]. Nevertheless, the SSA obtained by both ACNFs were lower as compared to the studies reported elsewhere [9]. It is believed that the carbonization and activation process of the ACNFs might be incomplete, and thus contributed to low SSA when analyzed by BET analysis. Thus, longer duration of activation and carbonization might be required.

Table 1. Specific surface area of NFs and ACNFs

\begin{tabular}{lcc}
\hline \multirow{2}{*}{ Sample } & \multicolumn{2}{c}{ Specific Surface Area $\left(\right.$ S.S.A) $\left(\mathbf{m}^{2} / \mathbf{g}\right)$} \\
\cline { 2 - 3 } & Before Activation & After Activation \\
\hline Neat ACNFs & 9.13 & 67.60 \\
ACNFs/ZnO & 8.91 & 163.04 \\
\hline
\end{tabular}




\section{SEM/FESEM - EDX analysis}

The structural morphologies of neat ACNFs and composite ACNFs are shown in Figure 3. It can be seen that the neat ACNFs possessed more aligned and straight fibers while the PAN-ZnO ACNFs showed more compact arrangement with bent surfaces. The result obtained is in agreement to study conducted by Imtiaz et al. where the activation process and the presence of $\mathrm{ZnO}$ led to cross-sectional shrinkage and causing the surface of fibers became rougher and more compact [11]. It can also be seen that there are white spots present alongside the fibers (as indicated by circle marks) which this could be referred as $\mathrm{ZnO}$ which is dispersed as beads alongside the PAN-ZnO nanofibers. Dispersion of $\mathrm{ZnO}$ beads further supported with EDX mapping as depicted in Figure 4 confirmed that $\mathrm{ZnO}$ exists in the ACNFs.

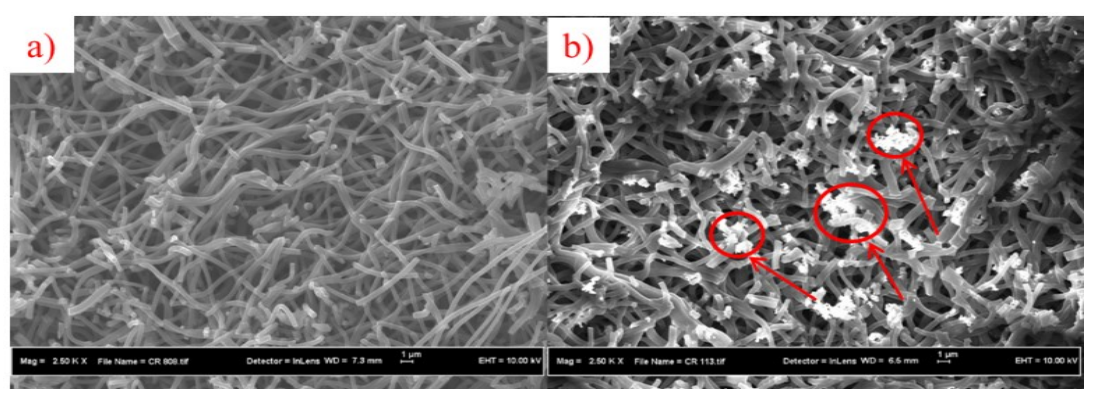

Figure 3. Structural morphologies of a) neat ACNFs and b) PAN-ZnO ACNFs

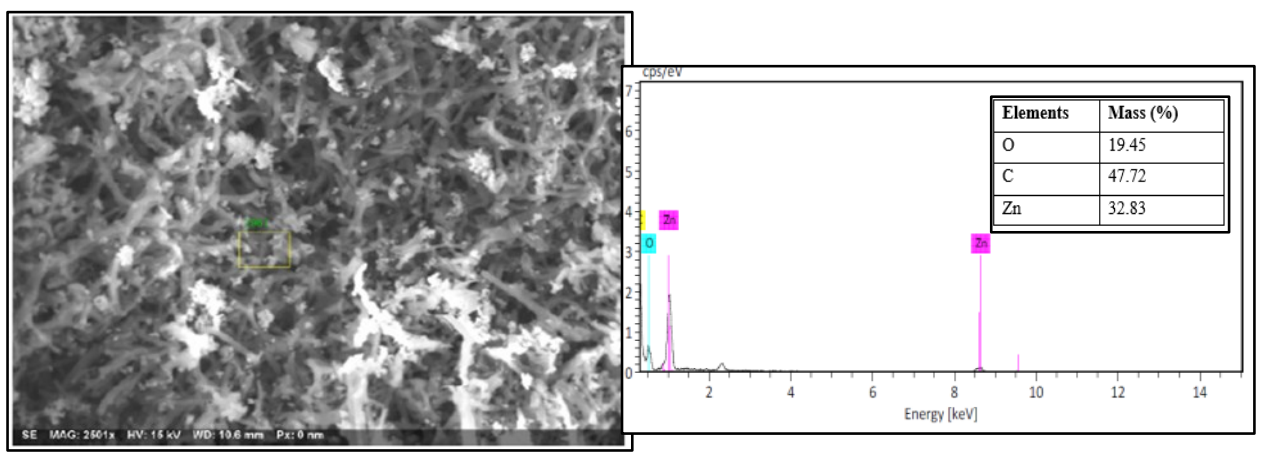

Figure 4. EDX mapping and elemental analysis of PAN-ZnO ACNFs

\section{FTIR analysis}

Figure 5 displays the FTIR spectrum of neat and PAN/ZnO based ACNFs. It can be seen that the activation process removed nitrile groups $(\mathrm{C} \equiv \mathrm{N})$ and methylene group $\left(\mathrm{CH}_{2}\right)$, only carbon and hydrogen remain as observed at wavelength peaks of $1573 \mathrm{~cm}^{-1}$ and $1250 \mathrm{~cm}^{-1}$ indicating aromatic C-C groups and alkyl halides $\mathrm{C}-\mathrm{H}$ groups [9]. In addition, absorption peak at $436.5 \mathrm{~cm}^{-1}$ was identified as $\mathrm{Zn}-\mathrm{O}$, indicating the presence of $\mathrm{ZnO}$ nanoparticles in the composite ACNFs [11]. The result is supported by EDX-mapping as displayed by Figure 4 previously, which showing the presence of elements $\mathrm{Zn}$. 


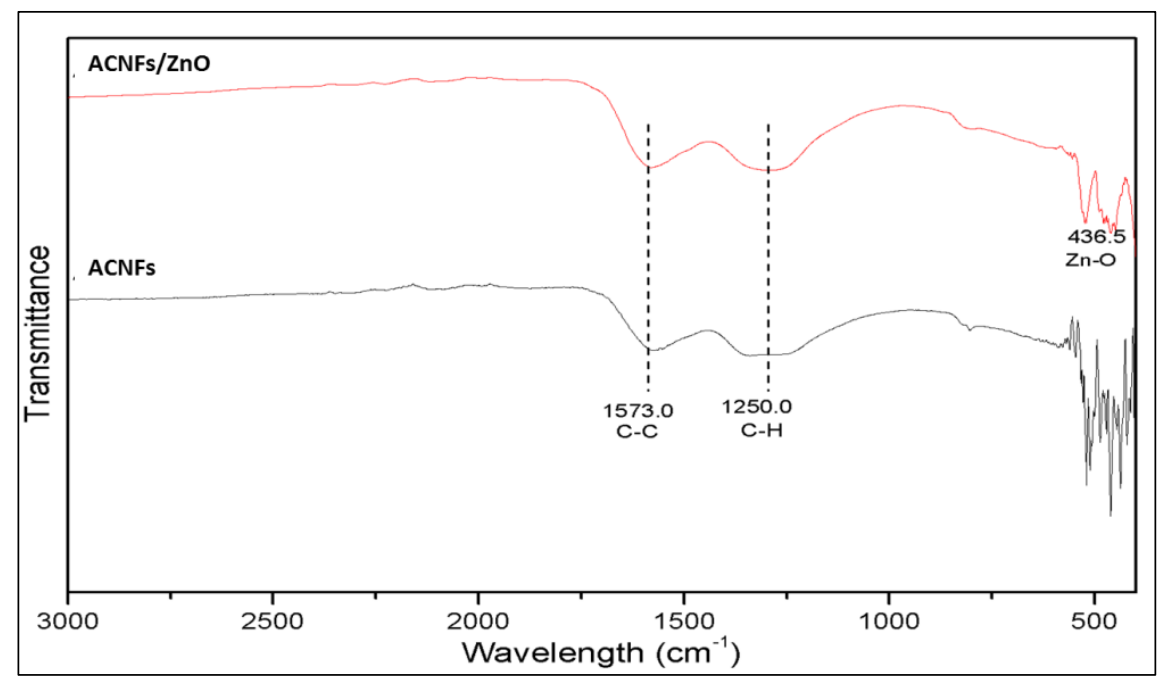

Figure 5. FTIR spectrum of ACNFs and ACNFs/ ZnO

\section{Adsorptive performance of ACNFs on Pb removal \\ Effect of $p H$}

The adsorption of $\mathrm{Pb}$ (II) on $\mathrm{ACNFs} / \mathrm{ZnO}$ at different $\mathrm{pH}$ (1.0 to 6.0) was conducted and the results are shown in Figure 6. The $\mathrm{pH}$ values higher than 6 was not tested in order to avoid precipitation of $\mathrm{Pb}(\mathrm{II})$ with $\mathrm{OH}^{-}$ions which will form lead salts as well as to avoid any inaccuracy [11]. It can be seen from the figure that increasing pH of the $\mathrm{Pb}$ solution increased the removal efficiency. For neat ACNFs, the removal efficiency of $\mathrm{Pb}$ is $20.1 \%(\mathrm{pH} 1.0)$ to $99.4 \%$ ( $\mathrm{pH} 4.0$ ). After $\mathrm{pH} 4.0$, there is no increment of removal was obtained. Therefore, the optimum $\mathrm{pH}$ of $\mathrm{Pb}$ (II) removal on ACNFs is from $\mathrm{pH} 4.0$ to $\mathrm{pH}$ 6.0. Similarly, for ACNFs/ZnO, increasing the $\mathrm{pH}$ caused a gradual increase of $\mathrm{Pb}$ (II) removal from $20.0 \%$ (pH 1.0) to $99.4 \%$ ( $\mathrm{pH} \mathrm{6.0)} \mathrm{in} \mathrm{which} \mathrm{the} \mathrm{optimum} \mathrm{pH}$ for removal of $\mathrm{Pb}$ on $\mathrm{ACNFs} / \mathrm{ZnO}$ is at $\mathrm{pH}$ 6.0. From the $\mathrm{pH}$ study, it can be seen that both ACNFs and ACNFs/ZnO have good removal efficiency which was more than $99.0 \%$. From the trend shown by both ACNFs, it is evident that the removal of $\mathrm{Pb}$ (II) is strongly related to $\mathrm{pH}$ which is related to the protonation of the functional groups existed in ACNFs. In acidic condition, low adsorption efficiency was achieved due to the competition between $\mathrm{H}+$ and metal ions for active sorption sites while at higher $\mathrm{pH}$ value, thus permitting the attraction between the metal ions and the surface of the adsorbent $[8,9]$.

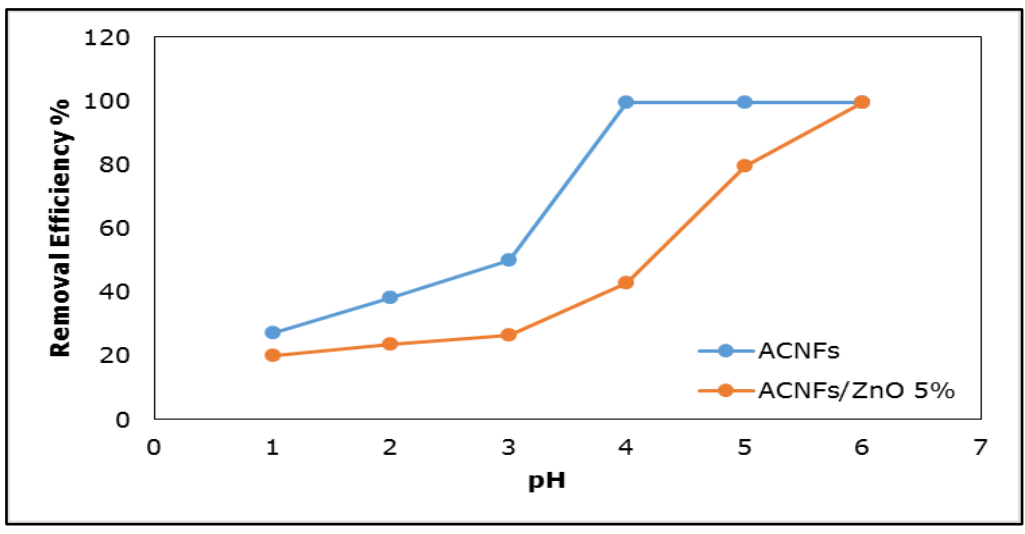

Figure 6. Effects of $\mathrm{pH}$ on removal of $\mathrm{Pb}(\mathrm{II})$ 


\section{Effect of initial concentration}

Figure 7 depicts the removal of $\mathrm{Pb}$ (II) by neat and $\mathrm{PAN}-\mathrm{ZnO}$ ACNFs with respect to different initial concentration $(10-121 \mathrm{mg} / \mathrm{L})$ of $\mathrm{Pb}$ (II) solution. For both ACNFs, it can be seen that the percentage of adsorption capacity increased with the increase of initial concentration. The highest adsorption capacity achieved for neat ACNFs was $77.60 \mathrm{mg} / \mathrm{g}$. whereas the highest adsorption capacity achieved for ACNFs $/ \mathrm{ZnO} 5 \%$ was $120.3 \mathrm{mg} / \mathrm{g}$. For carbonbased adsorbents, the adsorptive capabilities are contributed surface area, pore volume as well as minor role of surface functional groups which adsorb the ions. For the adsorption process, enhancing the former features is necessary as higher SSA and pore volume facilitate the adsorption process due to the availability of more binding sites [11]. As discussed in the previous section, the SSA of ACNFs/ZnO were higher than the neat ACNFS. Thus, the higher adsorption capacity may be attributed to the higher number of active sites provided by $\mathrm{ZnO}$. It is possible that addition of $\mathrm{ZnO}$ increased the active adsorption sites that increase the adsorption capacity of composite ACNFs towards $\mathrm{Pb}$ (II) [9]. The satisfactory adsorption capacity also contributed due to the fact that $\mathrm{ZnO}$ itself is adsorbent and very favorable towards sorption of heavy metals [9].

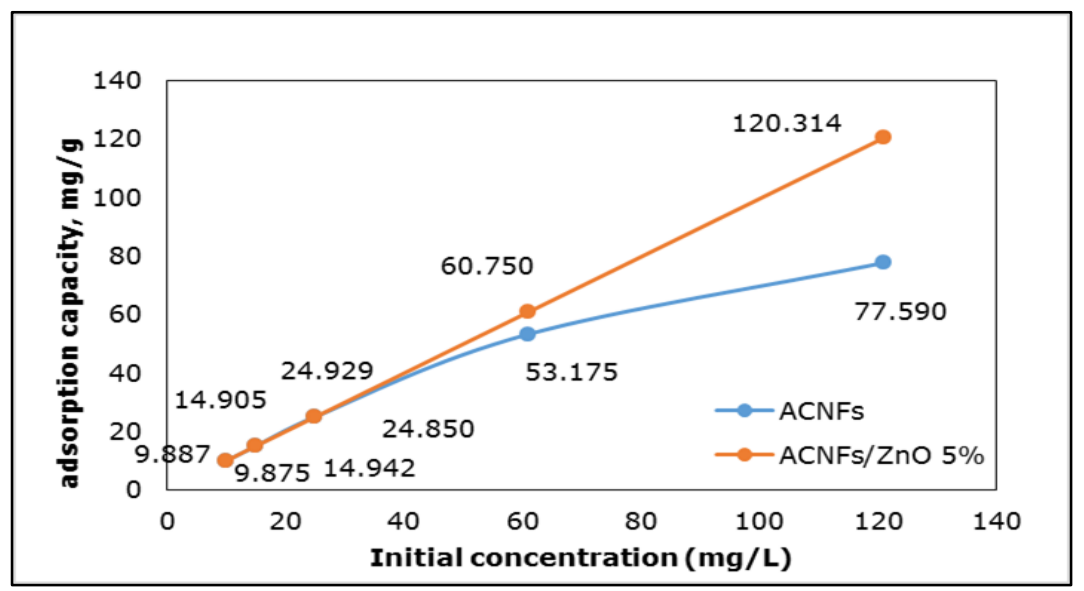

Figure 7. Effect of initial concentration

\section{Adsorption isotherm study}

In order to evaluate the mechanism of adsorption occurred on the surface of adsorbent, Langmuir and Freundlich isotherm models were applied and the results are presented in Table 2. As refer to Table 2, the $\mathrm{R}^{2}$ values from Freundlich model (0.960) for ACNFs was higher than Langmuir model (0.608). Similar results were obtained for $\mathrm{ACNFs} / \mathrm{ZnO}$ in which the $\mathrm{R}^{2}$ values from Freundlich model (0.958) was higher than Langmuir model (0.939). Thus, Freundlich isotherm model is best fitted to describe the adsorption behaviour that took place between the ACNFs and $\mathrm{ACNFs} / \mathrm{ZnO}$ with $\mathrm{Pb}$ (II) ions. From that, it is assumed that the attachment of $\mathrm{Pb}$ (II) ions occurred at heterogeneous surface of the neat ACNFs and ACNFs/ZnO [11].

Table 2. Langmuir and Freundlich isotherm parameters

\begin{tabular}{lcccccc}
\hline \multirow{2}{*}{ Adsorbent } & \multicolumn{3}{c}{ Langmuir Model } & \multicolumn{3}{c}{ Freundlich Model } \\
\cline { 2 - 7 } & $\begin{array}{c}\mathbf{Q}_{\max } \\
(\mathbf{m g} / \mathbf{g})\end{array}$ & $\begin{array}{c}\mathbf{b} \\
(\mathbf{L} / \mathbf{m g})\end{array}$ & $\mathbf{R}^{\mathbf{2}}$ & $\begin{array}{c}\mathbf{K} \\
(\mathbf{m g} / \mathbf{g})\end{array}$ & $\mathbf{1 / n}$ & $\mathbf{R}^{\mathbf{2}}$ \\
\hline ACNFs & 54.6 & 0.778 & 0.608 & 9.314 & 0.882 & 0.960 \\
ACNFs/ZnO & 169.5 & 1.594 & 0.939 & 2.920 & 0.011 & 0.958 \\
\hline
\end{tabular}




\section{Norfadhilatuladha et al: REMOVAL OF LEAD(II) FROM AQUEOUS SOLUTION USING \\ POLYACRYLONITRILE/ZINC OXIDE ACTIVATED CARBON NANOFIBERS}

\section{Conclusion}

In this study, the feasibility of $\mathrm{ACNF} / \mathrm{ZnO}$ to remove $\mathrm{Pb}$ (II) from aqueous solution was demonstrated. The specific surface area was increased by addition of zinc oxide in the ACNFs component. Under SEM analysis the $\mathrm{ACNFs} / \mathrm{ZnO}$ were found to have compact arrangement with dispersion of $\mathrm{Zn}$ beads. The adsorption studies revealed that the removal was dependant on $\mathrm{pH}$ and the adsorption mechanism were best fitted to be described by Freundlich model with the highest adsorption capacity in this study was $120.3 \mathrm{mg} / \mathrm{g}$.

\section{Acknowledgement}

The authors would like to acknowledge the financial support from Malaysian Ministry of Education (Higher Institution Centre of Excellence) and Universiti Teknologi Malaysia under Grant No. R.J090301.7846.4J179 and Q.J130000.2546.12H54. The authors would also like to acknowledge the technical and management support from Research Management Centre (RMC), Universiti Teknologi Malaysia.

\section{References}

1. Sheet, I., Kabbani, A. and Holail, H. (2014). Removal of heavy metals using nanostructured graphite oxide, silica nanoparticles and silica/graphite oxide composite. Energy Procedia, 50: 130 - 138.

2. Flora, G., Gupta, D. and Tiwari, A. (2012). Toxicity of lead: A review with recent updates. Interdisciplinary Toxicology, 5:47- 58 .

3. Ghazy, S. E. and Ragab, A. H. (2007). Removal of lead ions from aqueous solution by sorptive-flotation using limestone and oleic acid. Iranian Journal of Chemistry and Chemical Engineering, 26: 83 - 92.

4. $\mathrm{Fu}, \mathrm{F}$. and Wang, Q. (2010). Removal of heavy metal ions from wastewaters: A review. Journal of Environmental Management, 92: 407 - 418.

5. Wang, G., Pan, C., Wang, L., Dong, Q., Yu, C., Zhao, Z. and Qiu, J. (2012). Activated carbon nanofiber webs made by electrospinning for capacitive deionization. Electrochimica Acta, 69: 65 - 70.

6. Nataraj, S. K., Yang, K. S. and Aminabhavi, T. M. (2012). Polyacrylonitrile-based nanofibers - A state-of-theart review. Progress Polymer Science, 37: 487 - 513.

7. Ramakrishna, S., Fujihara, K., Teo, W., Yong, T., Ma, Z. and Ramaseshan, R. (2013). Electrospun nanofiber: Solving global issues. Materials Today, 9(3): 40 - 50.

8. Dadvar, S., Tavanai, H. and Morshed, M. (2012). Effect of embedding $\mathrm{MgO}$ and $\mathrm{Al}_{2} \mathrm{O}_{3}$ nanoparticles in the precursor on the pore characteristics of PAN based activated carbon nanofibers. Journal of Analytical and Applied Pyrolysis, 98: 98 - 105.

9. Faghihian, H., Kooravand, M. and Atarodi, H. (2013). Synthesis of a novel carbon nanofiber structure for removal of lead. Korean Journal of Chemical Engineering, 30: 357 - 363.

10. Norhaniza, Y., Dipak, R., Ismail, A. F. and Takeshi, M. (2016). Microstructure of polyacrylonitrile-based activated carbon fibers prepared from solvent-free coagulation process. Journal of Applied Research and Technology, 14: $54-61$.

11. Imtiaz, A. and Rafique, U. (2011). Synthesis of metal oxides and its application as adsorbent for the treatment of wastewater effluents. International Journal of Chemical and Environmental Engineering, 2(6): 400 - 405. 